\title{
RASIO INTERVAL TRAINING DALAM LATIHAN SHADOW BULUTANGKIS TERHADAP POWER DAN KECEPATAN
}

\author{
Himawan Wismanadi ${ }^{* 1}$, Fatkur Rohman Kafrawi ${ }^{2}$, Made Pramono ${ }^{3}$, \\ Awang Firmansyah ${ }^{4}$, Afif Rusdiawan ${ }^{5}$ \\ Universitas Negeri Surabaya, Indonesia ${ }^{1,2,3,4}$ \\ IKIP Budi Utomo Malang, Indonesia ${ }^{5}$ \\ Email: himawanwismanadi@unesa.ac.id ${ }^{* 1}$, fatkurrohman@unesa.ac.id ${ }^{2}$,
} madepramono@unesa.ac.id ${ }^{3}$, awangfirmansyah@unesa.ac.id ${ }^{4}$,rusdiawan.a@gmail.com ${ }^{5}$

Received: 10 May 2020; Accepted 05 October 2020; Published 03 December 2020

Ed 2020; 5(2): 186-198

\begin{abstract}
ABSTRAK
Kecepatan dan power merupakan komponen fisik paling penting dalam olahraga bulutangkis dengan sistem skor 3 x 21 rally point saat ini. Tujuan dari penelitian ini adalah untuk mengetahui pengaruh pelatihan shadow bulutangkis dengan rasio interval training 1:1 dan 1:1/2 terhadap power dan kecepatan. Jenis penelitian menggunakan penelitian eksperimen dengan desain randomized group pre test and post test design. Subyek penelitian ini adalah mahasiswa laki-laki IKOR Universitas Negeri Surabaya angkatan 2018 yang dibagi secara acak ke dalam kelompok eksperimen 1 (K1) dan kelompok eksperimen 2 (K2) yang terdiri dari 10 orang coba per kelompok. Kelompok K1 diberikan pelatihan shadow bulutangkis dengan metode interval training 1:1 dan Kelompok K2 dengan metode interval training 1:1/2 dengan waktu latihan 15 detik. Tes power dilakukan menggunakan jump MD dan tes kecepatan dilakukan dengan tes lari cepat 30 Meter. Analisis data menggunakan uji t berpasangan didapatkan hasil signifikan pada variabel power dan kecepatan pada K1, sedangkan pada K2 juga signifikan pada variabel power dan kecepatan. Analisis kedua menggunakan uji t 2 sampel bebas dan didapatkan hasil tidak signifikan pada variabel power, sedangkan variabel kecepatan juga tidak signifikan. Jadi kesimpulannya latihan shadow bulutangkis dapat meningkatkan power dan kecepatan baik dengan rasio interval training 1:1 maupun 1:1/2. Latihan shadow bulutangkis dengan interval training 1:1/2 lebih direkomendasikan untuk meningkatkan power dan kecepatan karena secara rata-rata hasilnya lebih baik daripada latihan shadow bulutangkis dengan interval training 1:1.
\end{abstract}

Kata Kunci: Bulutangkis; Kecepatan; Power; Shadow; Interval Training

\section{RATIO OF INTERVAL TRAINING IN SHADOW BADMINTON TRAINING TOWARDS POWER AND SPEED}

\begin{abstract}
Speed and power are the most important physical components in badminton with the current rally point system. The purpose of this study was to determine the effect of badminton shadow training on power and speed. This research used experimental research with randomized group pre-test and post-test design. The subjects of this study were male students IKOR unesa 2018 class which were randomly divided into experimental group 1 (K1) and experimental group 2 (K2) consisting of 10 people per group. K1 group was given badminton shadow training with 1:1 interval training method and K2 group with 1:1/2 interval training method with 15 seconds training time. The power test is performed using jump MD and the speed test is carried out with a 30 Meter sprint test. Paired t test results were significant $(p<0.05)$ on power $(p$ $=0.035)$ and speed $(p=0.006)$ at $K 1$, whereas at $K 2$ were also significant at power $(p=0,000)$ and speed $(p=0.014)$. Independent sample t test results were not significant at the power $(p=0.190)$, while the speed was also not significant $(p=0.165)$. In conclusion, badminton shadow training can increase power and speed with both 1:1 or 1:1/2 interval training ratios. Shadow badminton training with 1:1/2 interval training is more to increase power and speed because on average the results are better than shadow badminton training with 1:1 interval training.
\end{abstract}

Keywords: Badminton; Speed; Power; Shadow; Interval Training 
Himawan Wismanadi, Fatkur Rohman Kafrawi, Made Pramono, Awang Firmansyah dan Afif Rusdiawan (2020)

Rasio Interval Training Dalam Latihan Shadow Bulutangkis Terhadap Power dan Kecepatan

Copyright $\odot$ 2020, Journal Sport Area

DOI: https://doi.org/10.25299/sportarea.2020.vol5(2).5019

How To Cite: Wismanadi, H., Kafrawi, F. R., Pramono, M., Firmansyah, A., \& Rusdiawan, A. (2020). Rasio Interval Training Dalam Latihan Shadow Bulutangkis Terhadap Power dan Kecepatan. Journal Sport Area, 5(2), 186-198.

\section{PENDAHULUAN}

Bulutangkis merupakan salah satu cabang olahraga unggulan di Indonesia. Berbagai macam pertandingan telah dilalui dengan mengukir sejarah prestasi yang luar biasa untuk Indonesia (Rusdiawan \& Habibi, 2019). Namun akhir-akhir ini prestasi bulutangkis Indonesia sangat merosot, seperti sering gagalnya Indonesia meraih kembali piala Thomas dan piala uber. Terakhir kali Indonesia meraih piala Thomas pada tahun 2002 di Guangzhou Tiongkok, sedangkan piala uber terakhir pada tahun 1996 di Hongkong (Wikipedia, 2018). Penyebab menurunnya prestasi bulutangkis indonesia dikarenakan bermacam-macam sebab, sehingga diperlukan penanganan intensif berbagai aspek pendukung termasuk segi pembinaan dan pelatihan yang dapat membantu untuk memaksimalkan pencapaian prestasi.

Karakteristik olahraga bulutangkis saat ini sangat berbeda dengan zaman dulu. Zaman dahulu permainan bulutangkis mengutamakan keindahan dan tipuan sehingga terkesan bermain cantik dan cerdik, sedangkan bulutangkis pada saat ini berubah pola menjadi speed dan power games yang mengandalkan kecepatan dan kekuatan. Hal tersebut dikarenakan akibat perubahan pada sistem pengitungan poin dari game 15 menjadi game 21 dengan rally point (Wismanadi, 2011).

Dengan perubahan model permainan bulutangkis, maka terjadi pula perubahan pemberian latihan karena harus disesuaikan dengan kebutuhan energy dan fisik dengan permainan bulutangkis yang terkini. Banyak model latihan yang dapat digunakan untuk meningkatkan kapasitas fisik atlet bulutangkis sesuai dengan kebutuhannya, misalnya bentuk bentuk latihan circuit, fartlek, cross country, skipping rope, plyometric dan interval training.

Lama masa istirahat setiap perolehan angka memerlukan jeda antara 10-15 detik sampai dengan angka 21, maka sebaiknya atlet dibiasakan untuk berlatih dengan waktu yang mendekati sebenarnya (Wismanadi, 2011). Dengan latihan shadow bulutangkis, maka atlet akan melakukan gerakan-gerakan memukul dan mengejar shuttlecock seperti dalam permainan bulutangkis sebenarnya, namun dilakukan tanpa menggunakan shuttlecock. Latihan bulutangkis seperti ini serta diatur durasi latihannya sesuai dengan pada saat bermain sesungguhnya akan memberikan efek yang baik bagi atlet bulutangkis. Seperti penelitian oleh Kusuma yang menyatakan bahwa pelatihan shadow bulutangkis berpengaruh terhadap peningkatan kelincahan dan kecepatan reaksi (Kusuma, 2013). Yuksel dan Aydos (2018) dalam penelitiannya mengungkapkan bahwa latihan shadow dapat meningkatkan power anaerobic, vertical jump, kecepatan, keseimbangan, Vo2Max.

Latihan shadow bulutangkis dilakukan seperti permainan bulutangkis sebenarnya, namun perbedaannya adalah latihan shadow dilakukan hanya dengan memukul bayangan saja tanpa memukul shuttlecock yang sebenarnya. Walaupun latihan shadow dilakukan dengan memukul bayangan saja, namun gerakannya sama dengan permainan bulutangkis yang sebenarnya yaitu ada gerakan lari mengejar shuttlecock baik ke kanan, ke kiri, ke depan atau ke belakang, melangkah dengan cepat, melompat untuk melakukan jump smash serta dan memukul shuttlecock secara bayangan. Gerakan- 
gerakan itu dilakukan sesuai dengan aba-aba pelatih atau dengan mengikuti sinyal lampu yang menyala yang telah diprogram sebelumnya (Putro, 2015). Dari gerak latihan shadow yang berubah-ubah yang bersifat dinamis dan cepat itu, maka diharapkan akan mampu meningkatkan kecepatan dan power atlet.

Latihan dengan rasio yang berbeda akan menghasilkan efek yang berbeda. Latihan interval training dengan berbagai variasi durasi, set, repetisi dan intervalnya akan mempengaruhi efek fisiologis yang berbeda (Talanian, 2015). Namun tidak terdapat perbedaan efek fisiologis terhadap latihan dengan waktu kinerja dan interval yang berbeda (Piero, Valverde-Esteve, Redondo-Castán, Pablos-Abella, \& Díaz-Pintado, 2018).

Telah banyak dilakukan penelitian yang meneliti tentang pengaruh latihan shadow terhadap kecepatan, baik kecepatan lari maupun kecepatan reaksi. Pada penelitian ini peneliti mengukur bukan hanya kecepatan, tetapi juga power, karena terdapat kontribusi kecepatan yang mempengaruhi besarnya power (Mayhew, Piper, Schwegler, Ball, 1989). Selain itu, rasio latihan juga dibandingkan untuk mendapatkan hasil terbaik terhadap kecepatan dan powernya. Rasio latihan shadow bulutangkis dengan interval training 1:1 dan 1:1/2 adalah mengacu pada jeda waktu istirahat setelah shuttlecock dimainkan yang rata-rata sekitar 10-15 detik sehingga masa latihanpun harus disamakan dengan yang sebenarnya terjadi dalam permainan bulutangkis (Wismanadi, 2011). Dari uraian di atas, peneliti tertarik melakukan penelitian tentang perbedaan rasio interval training dalam latihan shadow bulutangkis terhadap power dan kecepatan.

\section{METODE PENELITIAN}

Penelitian ini menggunakan jenis penelitian eksperimen. Rancangan penelitian pre and post test group design pada dua kelompok dengan rancangan penelitian sebagai berikut:

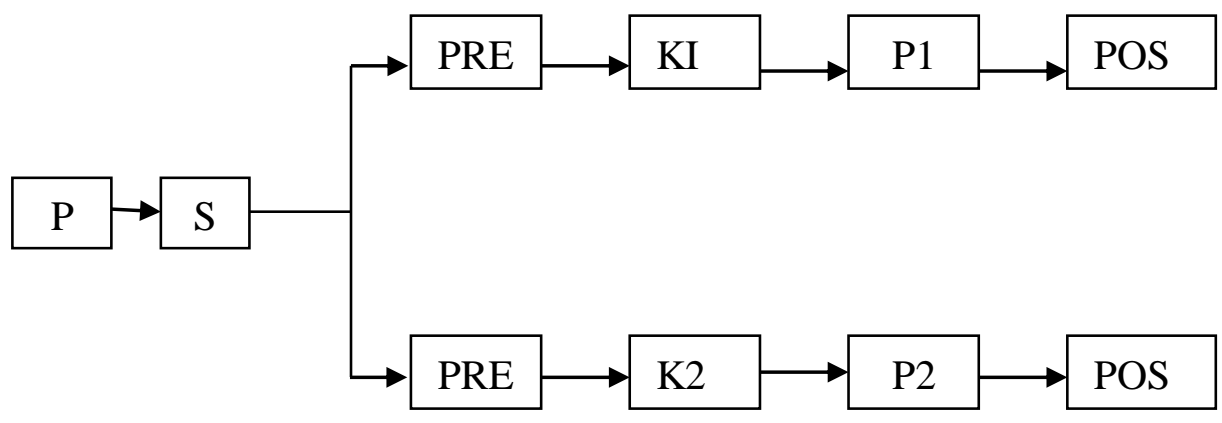

Gambar 1. Desain Penelitian

Populasi penelitian ini adalah mahasiswa IKOR Universitas Negeri Surabaya angkatan tahun 2018 yang dibagi secara purposive sampling ke dalam kelompok eksperimen 1 (K1) dan kelompok eksperimen 2 (K2) dengan kriteria berjenis kelamin laki-laki, usia 18-20 tahun dengan berat badan 60-70 kg serta sedang mengikuti mata kuliah pilihan bulutangkis. Orang coba yang memenuhi kriteria terdapat 20 orang dan kemudian dijadikan sampel dengan jumlah 10 orang coba per kelompok. Kelompok K1 diberikan pelatihan shadow bulutangkis dengan metode interval training 1:1 dan Kelompok K2 dengan metode interval training 1:1/2 dengan 
Himawan Wismanadi, Fatkur Rohman Kafrawi, Made Pramono, Awang Firmansyah dan Afif Rusdiawan (2020)

Rasio Interval Training Dalam Latihan Shadow Bulutangkis Terhadap Power dan Kecepatan

waktu latihan 15 detik. Pelatihan shadow bulutangkis dan pengambilan data penelitian dilakukan di GOR Bima dan lapangan atletik Universitas Negeri Surabaya.

Instrumen penelitian menggunakan tes lapangan. Data yang diambil yaitu power otot kaki yang diukur dengan menggunakan alat Jump $M D$ merk Takei buatan Jepang. Tes dilakukan dengan melakukan lompatan setinggi tingginya pada bidang alas Jump MD (Pembayun, Wiriawan, \& Setijono, 2018). Setelah melakukan lompatan, jump MD akan menunjukkan hasil lompatan. Data hasil tes menggunakan Jump $M D$ adalah tinggi lompatan (h) dengan satuan $\mathrm{cm}$ yang kemudian dikonversikan ke dalam power dengan satuan watt menggunakan rumus:

$$
\mathrm{P}=\frac{m \times g \times h}{t}
$$

Keterangan:

$$
\begin{array}{ll}
\mathrm{P} & =\text { Power }(\mathrm{watt}) \\
\mathrm{m} & =\operatorname{massa}(\mathrm{kg}) \\
\mathrm{g} & =\operatorname{gravitasi}(9,8 \mathrm{~m} / \mathrm{s}) \\
\mathrm{h} & =\operatorname{tinggi} \text { lompatan }(\mathrm{m}) \\
\mathrm{t} & =\text { waktu }(\mathrm{s}) \quad(\text { Haryono \& Pribadi, 2012) }
\end{array}
$$

Kemudian data berikutnya yang diambil adalah kecepatan lari. Data kecepatan lari diperoleh dengan melakukan tes lari cepat sejauh $30 \mathrm{~m}$ yang kemudian diambil waktunya dalam detik (Young Russell, Burge, Clarke, Cormack, \& Stewart, 2008). Semua tes dilakukan 2 kali dan diambil nilai terbaik serta dilakukan saat pre test dan post test.

Latihan shadow dalam penelitian ini dilakukan tanpa shuttlecock dengan bergerak mengikuti arah bola lampu yang menyala. Latihan shadow dilakukan di GOR Bima Universitas Negeri Surabaya. Latihan dibagi menjadi 2 kelompok dengan pola yang berbeda. Pada Kelompok K1 diberikan pelatihan shadow bulutangkis dengan metode interval training 1:1 sedangkan Kelompok K2 dengan metode interval training 1:1/2 dengan waktu latihan 15 detik. Pelatihan shadow diberikan sebanyak 3 kali seminggu selama 6 minggu (18 kali). Untuk lebih jelasnya lihat tabel 1.

Tabel 1. Program Pelatihan Shadow Bulutangkis dengan Interval Training Kelompok K1

\begin{tabular}{ccccccc}
\hline No & $\begin{array}{c}\text { Minggu } \\
\text { Ke- }\end{array}$ & $\begin{array}{c}\text { Waktu } \\
\text { Latihan }\end{array}$ & Set & Repetisi & Istirahat/Repetisi & Istirahat/Set \\
\hline 1 & I & 15 detik & 2 & 21 & 15 detik & 5 menit \\
2 & II & 15 detik & 2 & 21 & 15 detik & 5 menit \\
3 & III & 15 detik & 2 & 22 & 15 detik & 5 menit \\
4 & IV & 15 detik & 2 & 22 & 15 detik & 5 menit \\
5 & V & 15 detik & 2 & 23 & 15 detik & 5 menit \\
6 & VI & 15 detik & 2 & 23 & 15 detik & 5 menit \\
\hline
\end{tabular}

Ket: Latihan shadow dilakukan dengan mengikuti bola lampu yang menyala dan dilakukan 3 kali per minggu, repetisi meningkat setiap 2 minggu 
Himawan Wismanadi, Fatkur Rohman Kafrawi, Made Pramono, Awang Firmansyah dan Afif Rusdiawan (2020)

Rasio Interval Training Dalam Latihan Shadow Bulutangkis Terhadap Power dan Kecepatan

Tabel 2. Program Pelatihan Shadow Bulutangkis dengan Interval Training Kelompok K2

\begin{tabular}{ccccccc}
\hline \multicolumn{6}{c}{ Rasio Latihan 1: $\mathbf{1} \mathbf{2}$ dengan Waktu Latihan 15 Detik } \\
\hline No & $\begin{array}{c}\text { Minggu } \\
\text { Ke- }\end{array}$ & $\begin{array}{c}\text { Waktu } \\
\text { Latihan }\end{array}$ & Set & Repetisi & Istirahat/Repetisi & Istirahat/set \\
\hline 1 & I & 15 detik & 2 & 21 & 7,5 detik & 2,5 menit \\
2 & II & 15 detik & 2 & 21 & 7,5 detik & 2,5 menit \\
3 & III & 15 detik & 2 & 22 & 7,5 detik & 2,5 menit \\
4 & IV & 15 detik & 2 & 22 & 7,5 detik & 2,5 menit \\
5 & V & 15 detik & 2 & 23 & 7,5 detik & 2,5 menit \\
6 & VI & 15 detik & 2 & 23 & 7,5 detik & 2,5 menit \\
\hline
\end{tabular}

Ket: Latihan shadow dilakukan dengan mengikuti bola lampu yang menyala dan dilakukan 3 kali per minggu, repetisi meningkat setiap 2 minggu

Analisis data dalam penelitian ini menggunakan uji deskriptif, uji normalitas, uji t berpasangan dan uji t2 sampel bebas dengan bantuan progam SPSS seri 22.

\section{HASIL DAN PEMBAHASAN}

\section{Hasil Analisis Deskriptif Sampel}

Untuk mengetahui karakteristik sampel penelitian, peneliti melakukan analisis deskriptif sampel penelitian. Hasil analisis deskriptif sampel penelitian disajikan pada tabel 3 .

Tabel 3. Rerata dan Standard Deviasi (SD) Usia (Tahun) dan Berat Badan (Kg) Sampel

\begin{tabular}{ccc} 
& \multicolumn{2}{c}{ Penelitian } \\
\hline \multirow{2}{*}{ Kelompok } & \multicolumn{2}{c}{ Rerata \pm SD Usia dan BB } \\
\cline { 2 - 3 } & Usia (tahun) & BB (kg) \\
\hline K1 & $18,6 \pm 0,52$ & $65,5 \pm 4,09$ \\
K2 & $18,8 \pm 0,63$ & $65,6 \pm 3,20$ \\
\hline
\end{tabular}

Dari hasil analisis deskriptif sampel penelitian didapatkan hasil sesuai dengan kriteria pada kedua kelompok yaitu usia 18-20 tahun data berat badan 60-70 kg.

2. Hasil Analisis Deskriptif Berat Badan, Vertical Jump, Waktu dan Power Sebelum Serta Setelah Perlakuan

Sebelum melakukan analisis lebih lanjut, peneliti memaparkan hasil penelitian masing-masing variabel berdasarkan analisis deskriptif. Hasil analisis deskriptif massa tubuh, vertical jump, waktu dan power pada subyek penelitian disajikan pada tabel 4.

Tabel 4. Rerata \pm SD Massa Tubuh, Vertical Jump, Waktu dan Power

\begin{tabular}{cccccccc}
\hline \multirow{2}{*}{ Kelompok } & $\begin{array}{c}\text { Massa } \\
\text { Tubuh }\end{array}$ & \multicolumn{2}{c}{$\begin{array}{c}\text { Vertical Jump } \\
(\mathbf{c m})\end{array}$} & \multicolumn{2}{c}{ Waktu (s) } & \multicolumn{2}{c}{ Power (watt) } \\
\cline { 3 - 8 } & $(\mathbf{k g})$ & pre & Post & Pre & post & pre & Post \\
\hline \multirow{2}{*}{ K1 } & $65,5 \pm 4,0$ & $0,61 \pm 0$, & $0,66 \pm 0$, & $0,40 \pm 0$, & $0,41 \pm 0,0$ & $965,04 \pm 10$ & $1023,25 \pm 5$ \\
& 9 & 06 & 04 & 03 & 2 & 3,17 & 8,14 \\
\multirow{2}{*}{ K2 } & $65,6 \pm 3,2$ & $0,61 \pm 0$, & $0,68 \pm 0$, & $0,40 \pm 0$, & $0,41 \pm 0,0$ & $976,04 \pm 63$, & $1072,54 \pm 6$ \\
& 0 & 3 & 03 & 02 & 2 & 82 & 2,70 \\
\hline
\end{tabular}


Himawan Wismanadi, Fatkur Rohman Kafrawi, Made Pramono, Awang Firmansyah dan Afif Rusdiawan (2020)

Rasio Interval Training Dalam Latihan Shadow Bulutangkis Terhadap Power dan Kecepatan

Keterangan:

$\mathrm{K} 1=$ kelompok yang diberi pelatihan shadow dengan interval training 1:1 dengan masa waktu latihan 15 detik.

$\mathrm{K} 2$ = kelompok yang diberi pelatihan shadow dengan interval training 1:1/2 dengan masa latihan 15 detik.

Dari tabel 4 di atas menunjukkan nilai power pada kelompok K1 maupun K2 mengalami peningkatan dari hasil pre test ke post test. Hal tersebut menunjukkan bahwa perlakuan latihan shadow bulutangkis meningkatkan power. Untuk lebih jelasnya dapat dilihat pada gambar 2 .

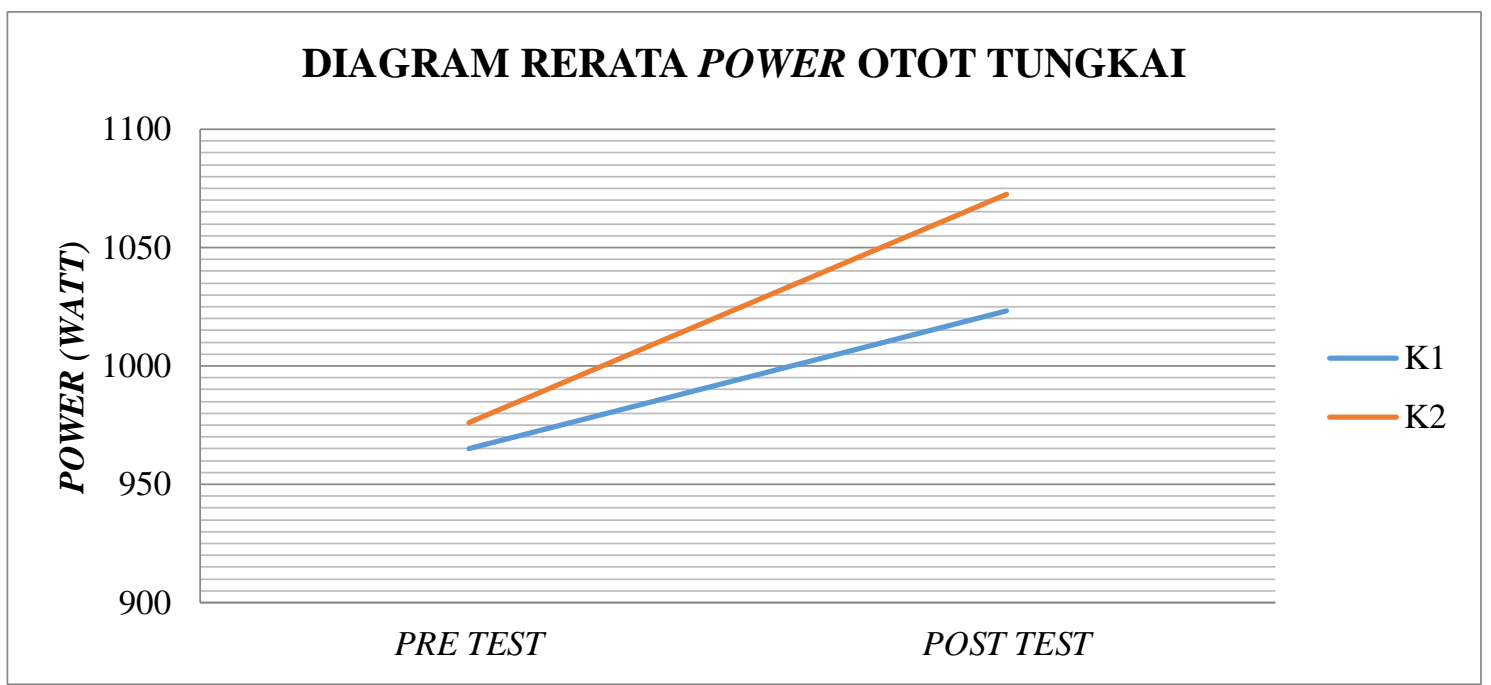

Gambar 2. Diagram Garis Rerata Power Pre Test dan Post Test Antar Kelompok

\section{Hasil Analisis Deskriptif Kecepatan Lari}

Data kecepatan lari didapatkan dari hasil tes lari dengan jarak 30 meter. Nilai yang dihitung adalah waktu lari dengan satuan detik. Subyek peneltian melakukan tes lari sebanyak 2 kali dan diambil data yang terbaik. Hasil analisis deskriptif kecepatan disajikan pada tabel 5 .

Tabel 5. Rerata dan Standart Deviasi (SD) Kecepatan Lari

\begin{tabular}{ccc}
\hline \multirow{2}{*}{ Kelompok } & \multicolumn{2}{c}{ Rerata \pm SD Kecepatan (Detik) } \\
\cline { 2 - 3 } & Pre Test & Post Test \\
\hline K1 & $4,67 \pm 0,24$ & $4,50 \pm 0,18$ \\
K2 & $4,54 \pm 0,15$ & $4,45 \pm 0,13$ \\
\hline
\end{tabular}

Dari tabel 4 di atas menunjukkan nilai kecepatan (dalam detik) baik pada kelompok $\mathrm{K} 1$ maupun kelompok $\mathrm{K} 2$ mengalami penurunan nilai post test dari nilai post test. Berikut diagram perbedaan data rerata kecepatan antara pre test dan post test antar kelompok. 
Himawan Wismanadi, Fatkur Rohman Kafrawi, Made Pramono, Awang Firmansyah dan Afif Rusdiawan (2020)

Rasio Interval Training Dalam Latihan Shadow Bulutangkis Terhadap Power dan Kecepatan

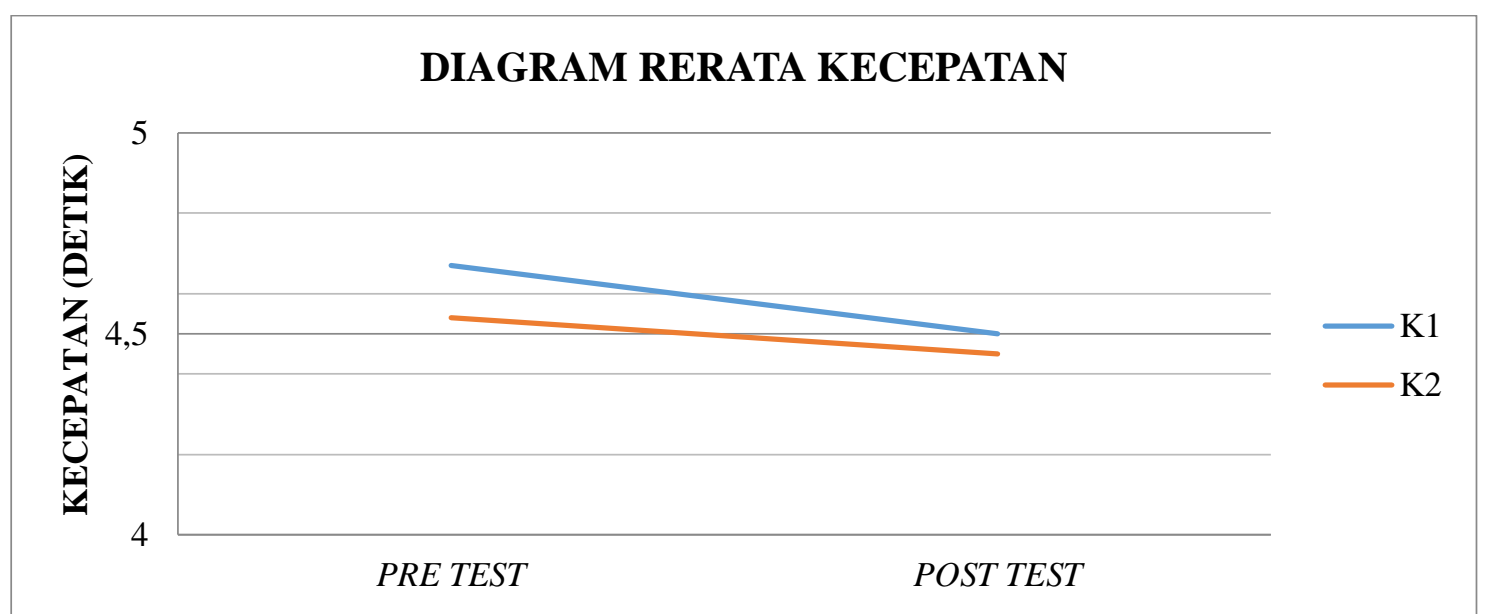

Gambar 3. Diagram Garis Rerata Kecepatan Pre Test dan Post Test Antar Kelompok

\section{Uji Normalitas}

Hasil uji normalitas variabel power dan kecepatan disajikan pada tabel 6. Hasil analisis menggunakan uji normalitas one sample kolmogorov smirnov test menunjukkan pada semua kelompok datanya berdistribusi normal dengan nilai $\mathrm{p}>0,05$.

Tabel 6. Hasil Uji Normalitas Power dan Kecepatan

\begin{tabular}{ccccc}
\hline \multirow{2}{*}{ Kelompok } & \multicolumn{4}{c}{ Nilai p (sig) } \\
\cline { 2 - 5 } & \multicolumn{2}{c}{ Power } & Kecepatan \\
\hline & Pre & Post & Pre & Post \\
\hline K1 & 0,651 & 0,947 & 0,959 & 0,991 \\
K2 & 0,987 & 0,961 & 0,625 & 0,975 \\
\hline
\end{tabular}

p>0,05 menunjukkan data variabel berdistribusi normal

\section{Hasil Uji t Berpasangan}

Untuk mengetahui apakah ada pengaruh perlakuan terhadap subyek penelitian, maka perlu dilakukan uji berpasangan hasil pre test dan post test setiap variabel. Hasil uji t berpasangan pada variabel power dan kecepatan dapat dilihat pada tabel 7 .

Tabel 7. Hasil Uji t Berpasangan Power dan Kecepatan

\begin{tabular}{ccc}
\hline \multirow{2}{*}{ Kelompok } & \multicolumn{2}{c}{ Nilai p (sig) } \\
\cline { 2 - 3 } & Power & Kecepatan \\
\hline K1 & 0,035 & 0,006 \\
K2 & 0,000 & 0,014 \\
\hline
\end{tabular}

$\mathrm{P}<0,05$ menunjukkan terdapat perbedaan yang bermakna

Dari hasil analisis uji t berpasangan yang disajikan pada tabel 7 di atas menunjukkan bahwa nilai p (sig) power kelompok K1 adalah 0,035 dan K2 0,000, maka dapat disimpulkan bahwa terdapat perbedaan yang bermakna nilai pre test dan post test pada variabel power $(\mathrm{p}<0,05)$. Sedangkan pada variabel kecepatan menunjukkan nilai $\mathrm{p}$ (sig) 0,006 untuk kelompok K1 dan p (sig) 0,014 untuk kelompok K2. Hal tersebut juga dapat disimpulkan bahwa terdapat perbedaan yang bermakna nilai pre test dan post test pada variabel kecepatan $(\mathrm{p}<0,05)$. 
Himawan Wismanadi, Fatkur Rohman Kafrawi, Made Pramono, Awang Firmansyah dan Afif Rusdiawan (2020)

Rasio Interval Training Dalam Latihan Shadow Bulutangkis Terhadap Power dan Kecepatan

\section{Hasil Uji t 2 Sampel Bebas}

Data penelitian yang telah memenuhi syarat data normalitas selanjutnya data dianalisis dengan uji t 2 sampel bebas untuk mengetahui apakah terdapat perbedaan pengaruh antar kedua kelompok. Data pada variabel dikatakan memiliki perbedaan yang bermakna apabila nilai uji p<0,05. Hasil uji t 2 sampel bebas dapat dilihat pada tabel 8 .

Tabel 8. Hasil Uji t Berpasangan Power dan Kecepatan

\begin{tabular}{ccc}
\hline Kelompok & \multicolumn{2}{c}{ Nilai p (sig) } \\
\cline { 2 - 3 } & Power & Kecepatan \\
\hline Post - Pre & 0,190 & 0,165
\end{tabular}

$\mathrm{P}<0,05$ menunjukkan terdapat perbedaan yang bermakna

Hasil uji t 2 sampel bebas menunjukkan nilai p>0,05 pada variabel power dengan nilai p (sig) 0,190. Hal tersebut dapat disimpulkan bahwa tidak terdapat perbedaan yang bermakna nilai power pada kedua kelompok ( $p>0,05)$. Sedangkan pada variabel kecepatan didapatkan nilai p (sig) 0,165. Hal tersebut juga dapat disimpulkan bahwa tidak terdapat perbedaan yang bermakna nilai kecepatan pada kedua kelompok $(\mathrm{p}>0,05)$.

Penelitian ini bertujuan mengetahui pengaruh pelatihan shadow bulutangkis dengan rasio interval training 1:1 dan 1:1/2 terhadap power dan kecepatan. Berdasarkan hasil penelitian, pengaruh perlakuan latihan shadow bulutangkis dengan metode interval training akan dibahas pada bagian ini.

\section{Pengaruh Latihan Shadow Bulutangkis Terhadap Power dengan Metode Interval Training 1:1 dan Metode Interval Training 1: 1/2}

Hasil penelitian variabel power pada kelompok K1 menunjukkan hasil yang meningkat dari pre test dan post test (tabel 4). Sedangkan pada kelompok K2 juga menunjukkan hasil yang meningkat dari pre test dan post test (tabel 4). Kemudian hasil uji t berpasangan pada variabel power juga menunjukkan nilai yang signifikan baik kelompok K1 maupun kelompok K2. Hal tersebut dapat diartikan bahwa terdapat pengaruh pemberian latihan shadow bulutangkis dengan metode interval training 1:1 maupun metode interval training 1: 1/2 terhadap power.

Latihan shadow bulutangkis telah banyak dilakukan oleh para atlet untuk meningkatkan performanya dalam kompetisi. Dengan latihan shadow, atlet banyak mendapatkan manfaat atau kemajuan baik dari segi teknik maupun dari fisik. beberapa penelitian mengungkapkan bahwa latihan shadow dapat meningkatkan kelincahan, kecepatan reaksi, ketepatan smash, power anaerobic, vertical jump, kecepatan, keseimbangan, $\mathrm{VO}_{2}$ Maks. Yuksel dan Aydos (2018) dalam penelitiannya juga mengungkapkan bahwa latihan shadow dapat meningkatkan power anaerobic, vertical jump, kecepatan, keseimbangan, vo2 maks.

Sesuai dengan pernyataan bahwa latihan shadow bulutangkis adalah latihan pukulan bayangan tanpa menggunakan shuttlecock dengan bergerak cepat ke kanan depan, tengah, belakang dan kiri depan, tengah, belakang. Gerakan tersebut dilakukan secara acak berdasarkan lampu yang menyala yang sudah diprogram (Putro, 2015). Latihan shadow bulutangkis dalam penelitian ini dilakukan dengan gerakan-gerakan yang sama seperti gerakan ketika memukul shuttlecock seperti berlari mengejar shuttlecock dan melompat untuk melakukan jump smash. Oleh karena itu, latihan shadow akan 
memaksa otot kaki untuk berkontraksi dengan cepat. Tubuh akan menerima beban oleh tubuh itu sendiri ketika mendarat setelah melakukan loncatan saat jump smash kemudian dilanjutkan lagi dengan melakukan gerakan lain untuk memukul shuttlecock dari arah lain. Proses kembali bergerak dengan cepat sesaat setelah mendarat ini akan memberikan ekstra loading pada otot-otot kaki, terutama otot betis dan otot hamstring. Beban inilah yang dapat dikatakan sebagai bagian dari latihan power otot kaki (Wilk \& Voight, 2009; Ibo, 2014).

Menurut Sundari dan Sukadiyanto (2019) power adalah kemampuan otot untuk menjawab setiap rangsangan dalam waktu sesingkat mungkin dengan menggunakan kekuatan otot. Dari teori di atas dapat diambil kesimpulan bahwa power merupakan gabungan dari kecepatan dan kekuatan. Latihan shadow bulutangkis dapat meningkatkan kecepatan (Yuksel \& Aydos, 2018). Meningkatnya power setelah latihan shadow dapat juga diakibatkan karena kecepatan yang juga meningkat.

\section{Pengaruh Latihan Shadow Bulutangkis Terhadap Kecepatan dengan Metode Interval Training 1:1 dan Metode Interval Training 1: 1/2}

Hasil penelitian variabel kecepatan pada kelompok K1 menunjukkan hasil nilai ratarata yang menurun dari pre test dan post test (tabel 5). Sedangkan pada kelompok K2 juga menunjukkan hasil nilai rata-rata yang menurun dari pre test dan post test. Kemudian hasil uji t berpasangan pada variabel kecepatan menunjukkan nilai yang signifikan pada kelompok K1 dan pada kelompok K2. Penurunan nilai rata-rata kecepatan tersebut berarti bahwa subyek penelitian mempunyai kemampuan lari yang semakin cepat setelah diberikan perlakuan. sehingga dapat disimpulkan bahwa terdapat pengaruh pemberian latihan shadow bulutangkis dengan metode interval training 1:1 maupun metode interval training 1:1/2 terhadap kecepatan.

Cahyaningrum dan Asnar (2018) mengungkapkan bahwa latihan kombinasi shadow dan strokes buluangkis dapat meningkatkan kecepatan reaksi dan ketepatan smash. Kemudian Rahman dan Warni (2017) juga mengungkapkan bahwa ada pengaruh latihan shadow 8 terhadap agility pada pemain bulutangkis. Hal ini juga sesuai dengan penelitian Putro (2015) bahwa latihan shadow menggunakan aba-aba pelatih dapat meningkatkan footwork atlet bulutangkis. Sukesih (2013) juga mengungkapkan bahwa latihan shadow memberikan peningkatan yang baik terhadap kelincahan.

Latihan shadow bulutangkis dilakukan dengan gerakan yang cepat yang sesuai dengan gerakan sesungguhnya saat bermain bulutangkis, namun perbedaannya adalah latihan shadow dilakukan tanpa menggunakan shuttlecock (Putro, 2015). Sesuai dengan penelitian Yuksel dan Aydos (2018) tentang efek pelatihan bulutangkis bayangan pada beberapa fitur motorik pemain bulu tangkis yang didapatkan hasil tes kecepatan setelah perlakuan mengalami penurunan waktu (dari 4,68 detik menjadi 4,38 detik dengan tes lari 20 Meter oleh anak laki-laki usia 8-10 Tahun). Artinya, pemberian latihan shadow bulutangkis dapat mempercepat gerakan langkah kaki (Yuksel \& Aydos, 2018).

Nirendan dan Murugavel (2019) berpendapat bahwa latihan shadow merupakan latihan bulutangkis yang efektif. Latihan shadow banyak bermanfaat terhadap permainan bulutangkis apabila dilakukan dengan benar. Manfaat tersebut di antaranya adalah meningkatkan daya tahan, kecepatan, antisipasi, timing pukulan, dan kebugaran fisik. Latihan shadow walaupun dilakukan tanpa menggunakan shuttlecock tetapi akan memaksa pemain untuk bergerak ke beberapa posisi dan melakukan pukulan bayangan (Nirendan \& Murugavel, 2019). 
Kecepatan merupakan kemampuan untuk melakukan gerakan-gerakan yang sejenis secara berturut-turut dalam waktu sesingkat mungkin (Widodo, 2010). Latihan shadow bulutangkis dilakukan dengan cepat dan dilakukan berulang-ulang sesuai dengan 6 titik yang telah ditentukan. Gerakan-gerakan berpindah tempat dengan cepat ini yang dapat dikatakan dapat digunakan sebagai latihan untuk meningkatkan kecepatan.

\section{Perbedaan Pengaruh Latihan Shadow Bulutangkis dengan Metode Interval Training 1:1 dan Dengan Metode Interval Training 1:1/2 Terhadap Power dan Kecepatan}

Rasio latihan yang diberikan pada suatu latihan akan mempengaruhi tubuh secara anatomis dan fisiologis seperti kekuatan otot, kecepatan, daya tahan otot, stabilisasi otot, daya ledak otot dan koordinasi otot (Bompa \& Haff, 2009). Perbedaan latihan shadow bulutangkis metode interval training $1: 1$ dengan $1: 1 / 2$ terletak pada waktu istirahatnya yang akan berdampak secara fisiologis. Latihan shadow bulutangkis metode interval training 1:1 berarti durasi waktu latihan sama dengan durasi waktu istirahat, sedangkan metode interval training 1:1/2 berarti durasi waktu latihan 2 kali lipat durasi waktu istirahat atau durasi waktu istirahat adalah setengah durasi waktu latihan.

Hasil uji t 2 sampel bebas variabel power dan kecepatan (tabel 8) antara kelompok K1 dan K2 menunjukkan hasil yang tidak signifikan dengan nilai p (sig) 0,190 pada variabel power dan nilai p (sig) 0,190 pada variabel kecepatan. Hal tersebut berarti tidak terdapat perbedaan yang bermakna kemampuan power dan kecepatan antara kelompok K1 yang diberi pelatihan shadow bulutangkis metode interval training 1:1 dengan kelompok K2 yang diberi pelatihan shadow bulutangkis metode interval training 1: 1/2.

Latihan-latihan shadow tersebut dilakukan dengan program latihan yang berbeda dan durasi, frekuensi dan intensitas latihan yang berbeda. Seperti yang diungkapkan Seo, Lee, Jung, Jung, dan Song (2019) bahwa terdapat perbedaan power, kapasitas anaerobic dan Vo2Max terhadap atlet dengan berbagai variasi rasio latihan interval training. Hal tersebut juga sama diungkapkan oleh Rahimi (2005) bahwa terdapat perbedaan efek latihan dengan waktu kinerja, interval dan istirahat serta volume latihan yang berbeda. Latihan dengan dengan volume dan intensitas yang berbeda juga menyebabkan perbedaan pada hipertrofi otot dan kekuatannya (Mangine et al., 2015).

Seperti diketahui bahwa komponen fisik power dan kecepatan merupakan aktivitas fisik yang menggunakan sistem energi dominan anaerobik. Hasil penelitian menunjukkan tidak terdapat perbedaan yang bermakna antara pelatihan shadow bulutangkis metode interval training 1:1 dengan 1:1/2, karena pelatihan shadow bulutangkis metode interval training 1:1 dengan 1:1/2 yang diterapkan dalam penelitian ini intensitasnya sama-sama menggunakan sistem energi dominan anaerobik (aktifitas tinggi waktunya singkat). Jadi dampaknya terhadap power dan kecepatan relatif tidak ada perbedaan atau sama (Wismanadi, 2011).

\section{KESIMPULAN}

Pemberian pelatihan shadow bulutangkis metode interval training 1:1 maupun metode interval training 1:1/2 dapat meningkatkan kemampuan power dan kecepatan. Namun jika dibandingkan peningkatan power dan kecepatan antara metode interval training 1:1 dengan metode interval training 1:1/2 maka tidak didapatkan perbedaan yang bermakna. Hal tersebut dikarenakan metode interval training 1:1 dan metode interval training 1:1/2 sama-sama bentuk latihan yang bersifat anaerobic. Sehingga 
Himawan Wismanadi, Fatkur Rohman Kafrawi, Made Pramono, Awang Firmansyah dan Afif Rusdiawan (2020)

Rasio Interval Training Dalam Latihan Shadow Bulutangkis Terhadap Power dan Kecepatan

rekomendasi peneliti untuk penelitian selanjutnya adalah membandingkan metode latihan dengan bentuk dan rasio latihan yang lebih bervariasi untuk menentukan dosis latihan yang tepat.

\section{DAFTAR PUSTAKA}

Bompa, T. \& H. G. G. (2009). Periodization-6th Edition: Theory and Methodology of Training. United State of America: Human Kinetics.

Cahyaningrum, G. K., Asnar, E., \& Wardani, T. (2018). Perbandingan Latihan Bayangan dengan Drilling dan Strokes Terhadap Kecepatan Reaksi dan Ketepatan Smash. Jurnal SPORTIF: Jurnal Penelitian Pembelajaran, 4(2), 159-170. https://doi.org/10.29407/js_unpgri.v4i2.12328

Ibo, M. (2014). Melompat untuk Melatih Kekuatan dan Kecepatan. Retrieved October 28, 2019, from https://sport.detik.com/sepakbola/pandit/d-2781381/melompatuntuk-melatih-kekuatan-dan-kecepatan.

Haryono, S., \& Pribadi, F. S. (2012). Pengembangan Jump Power Meter Sebagai Alat Pengukur Power Tungkai. Media Ilmu Keolahragaan Indonesia, 2(1). https://doi.org/10.15294/miki.v2i1.2550

Kusuma, G. N. A. (2013). Pengaruh Pelatihan Bayangan (Shadow) Bulutangkis Terhadap Peningkatan Kelincahan Dan Kecepatan Reaksi. Jurnal Ilmu Keolahragaan Undiksha, 5(1), 1-8. http://dx.doi.org/10.23887/jiku.v1i1.1571

Mangine, G. T., Hoffman, J. R., Gonzalez, A. M., Townsend, J. R., Wells, A. J., Jajtner, A. R., ... Stout, J. R. (2015). The effect of training volume and intensity on improvements in muscular strength and size in resistance-trained men. Physiological Reports, 3(8), 1-17. https://doi.org/10.14814/phy2.12472

Mayhew, J. L., Piper, F. C., Schwegler, T. M., Ball, T. E. (1989). Contribution of Speed, Agility and Body Composition to Anaerobic Power Measurement in College Football Player. Journal of Strength and Conditioning Research, 3(4), 101-106.

Nirendan, J. M. K. (2019). Effect of shadow training on motor fitness components of badminton players. International Journal of Physiology, Sports and Physical Education, 1(2), 4-6.

Pembayun, D. L., Wiriawan, O., \& Setijono, H. (2018). Pengaruh Latihan Jump To Box, Depth Jump dan Single Leg Depth Jump Terhadap Peningkatan Kekuatan Otot Tungkai dan Power Otot Tungkai. Jurnal SPORTIF : Jurnal Penelitian Pembelajaran, 4(1), 87. https://doi.org/10.29407/js_unpgri.v4i1.12006 
Piero, D. W., Valverde-Esteve, T., Redondo-Castán, J. C., Pablos-Abella, C., \& DíazPintado, J. V. S. A. (2018). Effects of work-interval duration and sport specificity on blood lactate concentration, heart rate and perceptual responses during high $\begin{array}{lllll}\text { intensity interval training. PLoS ONE, } & \text { 13(7). }\end{array}$ https://doi.org/10.1371/journal.pone.0200690

Putro, B. R. H. (2015). Perbedaan Hasil Latihan Shadow Menggunakan Isyarat Lampu dan Aba-Aba Pelatih Terhadap Agility Footwork Atlet Bulutangkis PB Sehat Semarang. Skripsi. Universitas Negeri Semarang: Semarang.

Rahimi, R. (2005). Effect of different rest intervals on the exercise volume completed during squat bouts. Journal of Sports Science and Medicine, 4(4), 361-366.

Rahman, T., \& Warni, H. (2017). Pengaruh Latihan Shadow 8 Terhadap Agility Pada Pemain Bulutangkis PB. Mustika Banjarbaru Usia 12 - 15 Tahun. Jurnal Multilateral, 16(1), 16-24. https://doi.org/10.13140/RG.2.2.16821.17127

Rusdiawan, A., \& Habibi, A. I. (2019). Perbedaan Kadar Asam Laktat dan Tingkat Kelelahan Anaerobic Setelah Diberikan Jus Semangka Kuning dan Aktivitas Anaerobik. Prosiding Seminar Nasional IPTEK Olahraga (SENALOG), 2(1), 3137.

Seo, M. W., Lee, J. M., Jung, H. C., Jung, S. W., \& Song, J. K. (2019). Effects of Various Work-to-rest Ratios during High-intensity Interval Training on Athletic Performance in Adolescents. International Journal of Sports Medicine, 40(8), 503510. https://doi.org/10.1055/a-0927-6884

Sukesih. (2013). Penerapan Latihan Shadow Dalam Upaya Meningkatkan Kelincahan Pada Materi Permainan Bulutangkis (Penelitian Tindakan Kelas pada Siswa Kelas VI SD Negeri 2 Sokaraja Kulon Tahun Ajaran 2012/2013). Dinamika Jurnal Ilmiah Pendidikan Dasar, 7(1). 10.30595/dinamika.v7i1.921

Sundari, A., \& Sukadiyanto, S. (2019). Perbandingan metode latihan dan power otot lengan terhadap hasil tolak peluru. Jorpres (Jurnal Olahraga Prestasi), 15(1), 4756. https://doi.org/10.21831/jorpres.v15i1.26022

Talanian, J. L. (2015). Defining Different Types of Interval Training: Do we need to use more specific terminology?. Sports and Exercise Medicine - Open Journal, 1(5), 161-163. https://doi.org/10.17140/semoj-1-124

Widodo, S. (2010). Cara Mengembangkan Kecepatan Lari. Smart Sport, 3(1), 267-278.

Wikipedia. (2018). Piala Thomas - Wikipedia bahasa Indonesia, ensiklopedia bebas. Retrieved October 21, 2019, from https://id.wikipedia.org/wiki/Piala_Thomas

Wilk, K. E., \& Voight, M. L. (2009). Plyometrics for the Shoulder Complex. The Athlete's Shoulder (Second Edition). https://doi.org/10.1016/B978-0443067013.50058-X 
Himawan Wismanadi, Fatkur Rohman Kafrawi, Made Pramono, Awang

Wismanadi, H. (2011). pengembangan program pelatihan fisik bayangan rancang gerak bulutangkis dan pengurangan masa istirahat untuk peningkatan power, kecepatan reaksi dan recovery. Kepelatihan Olahraga, 6(1), 1-10.

Young, W., Russell, A., Burge, P., Clarke, A., Cormack, S., \& Stewart, G. (2008). The use of sprint tests for assessment of speed qualities of elite Australian rules footballers. International Journal of Sports Physiology and Performance, 3(2), 199-206. https://doi.org/10.1123/ijspp.3.2.199

Yüksel, M. F., \& Aydos, L. (2018). The effect of shadow badminton trainings on some the motoric features of badminton players. Journal of Athletic Performance and Nutrition, 4(2), 11-28. 